\begin{tabular}{lc}
\hline & ANNALES \\
& UNIVERSITATIS MARIAE CURIE-SKŁODOWSKA \\
LOL. V & LEBLIN - POLONIA \\
\hline
\end{tabular}

ISSN: 2451-0491 • e-ISSN: 2543-9340 - CC-BY 4.0 • DOI: 10.17951/en.2020.5.149-169

\title{
W imię spotkania. Antroponomastyka - lektura - etyka
}

\author{
In the Name of the Meeting. \\ Anthroponomastics - Reading - Ethics
}

\author{
Matgorzata Wójcik-Dudek \\ Uniwersytet Śląski w Katowicach. Wydział Humanistyczny \\ pl. Sejmu Śląskiego 1, 40-032 Katowice, Polska \\ malgorzata.wojcik-dudek@us.edu.pl \\ https://orcid.org/0000-0001-9032-8875
}

\begin{abstract}
The author of the article in an anthroponomastic interpretation of literary texts sees the chance to sensitize the young reader not only to the fate of the characters of the texts, but also to other people. De-digitization of the literary character's name proposed to students in Polish language lessons encourages them to resignation from interpretative schemes, enriching interpretation with a completely new context. In this sense, learning about language supports innovative readings, convincing students that literature lessons can become ethical workshops during which we improve the art of meeting with other people.
\end{abstract}

Keywords: anthroponomastic interpretation of literary texts; interpretation; new context; meeting

\begin{abstract}
Abstrakt. Autorka artykułu w antroponomastycznej interpretacji tekstów literackich dostrzega szansę na uwrażliwienie młodego czytelnika nie tylko na los bohaterów tekstów, lecz także na los drugiego człowieka. Deszyfryzacja imienia postaci literackiej zaproponowana uczniom na lekcjach języka polskiego zachęca do uwolnienia jej z interpretacyjnych schematów, wzbogacając interpretację o zupełnie nowy kontekst. W tym sensie nauka o języku wspiera innowacyjne odczytania tekstu, przekonując uczniów, że lekcje literatury mogą stać się warsztatami etycznymi, podczas których doskonali się sztukę spotkania z drugim człowiekiem.
\end{abstract}

Słowa kluczowe: antroponomastyczna interpretacja tekstów literackich; interpretacja; nowy kontekst; spotkanie 


\section{W OPIEKUŃCZYCH RAMIONACH NAWIASU}

Tadeusz Sławek (2002: 27), diagnozując w 2002 roku ówczesną kondycję uniwersytetu, stwierdził: „[...] gdy profesor zawsze uczy czegoś »obok«i $» w y z ̇ e j «$ kanonów swojej dyscypliny i dzięki temu staje się Mistrzem, instruktor ogranicza się do tego, co niezbędne i określone ścisłym wymogiem programu, nie »uczy«, lecz właśnie »instruuje «". Po niemal dwudziestu latach wydaje się, że powyższe stwierdzenie z początku XXI wieku nie tylko znakomicie antycypowało dające się dziś zauważyć procesy przekształcające uniwersytet rozumiany jako wspólnota $\mathrm{w}$ uniwersytet przypominający korporację, lecz także zapowiadało niepokojące tendencje w szkolnej edukacji, przedkładające efektywność, a czasem i efektowność nauczania nad niespektakularną powolność uczenia się.

Tę niepokojącą sytuację edukacyjną rozpoznaje Sławek (2019: 12) następująco: „[... ] taka dewolucja uczenia (się) oznacza porzucenie wszelkiej głębi na rzecz powierzchni, rezygnację z jakiejkolwiek fałdy spowodowaną fatalnym zauroczeniem gładkością tego, czego nie trzeba wywalczać, gdyż wymaga ono jedynie aktu przekazania i biernego przyjęcia tego przekazu”. Zapis zaimka zwrotnego się w nawiasie ma następujący sens: „Otaczamy więc »się« ramionami nawiasu, by zachować możliwość fałdy i głębi oraz niezbędnego dla uczenia (się) napięcia. Także po to, by te ramiona - () - chroniły tajemnicę uczenia się przed wścibskim wzrokiem pedantów i techno-biurokratów edukacji” (tamże).

Do tajemnicy uczenia dodałabym jeszcze inną wartość, dla której szkolny system nie bywa gościnny. Jest nią brak, niebędący jednak zadowoloną z siebie, cyniczną ignorancją, lecz szansą na ujrzenie i usłyszenie Innego oraz inności, wszak to właśnie na te wartości czekają opiekuńcze ramiona nawiasu - swoiste ramy metanoi czytelnika, dokonującej się w akcie lektury. Skoro „[c]zytać - to tyle, co pozwalać oddalać się wszelkiej pokusie jednoznaczności, której miałbym być dysponentem" (Sławek 2002: 118), to trzeba krytycznie spojrzeć na tych, którzy „przyzwyczaili się do wygodnych dróg, latarni morskich, słupów wiorstowych, dokładnych map, z góry zapowiadających każdy, nawet najmniejszy zakręt przyszłej drogi” (Szestow 2011: 146, cyt. za: Sławek 2019: 21). Porzućmy więc w szkolnej lekturze miejsca bezpieczne i spytajmy o imię.

\section{ANTROPONOMASTYKA I LEKTURA}

Stanisław Grzeszczuk w artykule Przedmiot $i$ zadania nazewnictwa literackiego (1963: 383-405) zastanawia się, czy nazewnictwo literackie należy do obszarów badań językoznawców czy raczej historyków literatury. Odpowiedź na tak postawione pytanie zadowala chyba wszystkich zainteresowanych, gdyż 
onomastyka literacka ${ }^{1}$, zajmująca się oglądem nazw własnych występujących w dziele literackim, zostaje wpisana w badania nad poetyką. Konieczność interdyscyplinarnego charakteru badań nad onomastyką, już nie tylko literacką, dostrzegali również filozofowie, choć ich diagnoza naukowa w kwestiach językowych w 1973 roku nie wydawała się czymś oczywistym. Eugeniusz Grodziński, wydając właśnie w tym roku Zarys ogólnej teorii imion własnych, przypomniał o pilnej potrzebie włączenia się filozofów w refleksję nad językiem, którzy „z dawien dawna uważają, że mają coś do powiedzenia w teoretycznych kwestiach języka, a pogłębienie nie zawsze jeszcze ścisłej współpracy między językoznawcami a filozofami w tych kwestiach byłoby, jak się zdaje, bardzo pożądane" (Grodziński 1973: 7). Przyjmując ustalenia Kazimierza Rymuta (1993: 15), skłaniającego się ku twierdzeniu, że przedmiotem badawczym onomastyki są „nazwy własne jako element językowy, ich budowa językowa, ich funkcje w systemie językowym oraz związki nazw własnych z sytuacją pozajęzykową", interdyscyplinarny charakter refleksji nad tą dziedziną nauki wydaje się dziś niezbywalny.

Szczególnie interesujący jest sposób włączenia zagadnień onomastycznych do interpretacji tekstów literackich. Mam wrażenie, że akademickie ustalenia w tym zakresie są słabo rozpoznane przez szkolną dydaktykę. Mimo że zagadnienia onomastyczne pojawiają się na lekcjach "językowych", to przypisywanie ich jedynie nauce o języku skutkuje izolacją ważnych ustaleń, które mogłyby nie tylko wzbogacić interpretację tekstu literackiego, ale przede wszystkim wpłynąć na odświeżenie szkolnej lektury czytanej często przez nauczycieli, ale i przez uczniów zgodnie z „programowym rozkładem jazdy”. Propozycja w żaden sposób nie rewolucjonizuje oglądu kanonicznych tekstów, wszak już w 1970 roku Aleksander Wilkoń, badając nazwy własne w prozie Stefana Żeromskiego, zaproponował przejrzystą klasyfikację ich funkcji w dziele literackim. Warto je dla porządku przypomnieć: lokalizacyjna, socjologiczna, aluzyjna, treściowa i ekspresywna (Wilkoń 1970). Inni badacze uzupełniają te ustalenia, dodając funkcję dydaktyczną (szczególnie popularną w literaturze dla dzieci i młodzieży²) (Kęsikowa 1988: 81-86), poetycką oraz wartościującą (Szewczyk 1990: 91-102).

1 Onomastyka literacka, wcześniej określana jako nazewnictwo stylistyczne, zaczęła się w Polsce rozwijać w latach 50 . O współczesnym rozumieniu tej „nauki pogranicza” w wyczerpujący sposób pisze Danuta Lech-Kirstein (2016: 457-466).

2 Z nowych opracowań onomastycznych z zakresu „literatury osobnej” warto przywołać książki Izabeli Łuc Nazwy własne w literaturze dziecięco-młodzieżowej (2007) oraz Marii Czaplickiej-Jedlikowskiej Edukacyjne aspekty nazw własnych w literaturze dla dzieci (2007). Małgorzata Dawidziak-Kładoczna (2015) wskazuje z kolei ciekawe ujęcie nazw własnych zastosowane we współczesnych utworach dla najmłodszych, w których wątek onimiczy organizuje cały tekst. Interesującym zagadnieniem wydaje się również przekład nazw własnych w tekstach dla młodych czytelników (por. Rajewska 2013; Rybicka 2013; Szymańska 2014). 
Rozważania dotyczące edukacji i lektury inspirowane pracami Sławka, uwzględniające istotną rolę onomastyki podczas interpretacji tekstu literackiego, nie mogą sprowadzać się jedynie do forsowania zadań w ramach warsztatów językowych. Językoznawczy fetysz nie powinien wszak przysłonić bardziej doniosłego celu spotkania z lekturą, choć na pewno wesprze czytającego w jego osiągnięciu. Namysł nad (językowym) detalem, tym, co zwykle pomijane, zagłuszane przez dążenie do spójności uznawanej za sukces szkolnej interpretacji, zmusza przecież czytelnika do powolności i uważności ${ }^{3}$. Przyzwyczaja do tego, czego uczy literatura, a o czym szkolna interpretacja zdaje się nie pamiętać. Jeśli przyjmiemy, że to właśnie interpretacja jest istotnym elementem kształtowania młodego człowieka, to wychowanie, w którym na poważnie potraktujemy jej rolę, prowadzi do:

[...] uprzytamniania niejednoznaczności słów i ich nieprzystawalności do świata; wyprowadzenie tego, co swojskie, w bezdomność, w której może narodzić się poważna refleksja o tożsamości; inspirowanie i dodawanie odwagi do ekspresji swojego splątanego doświadczenia; wytrącanie z samozadowolenia i otwieranie horyzontu [...], podnoszenie wartości człowieka przez wzmacnianie tego, co w nim kruche i wrażliwe [...]. (Maliszewski 2013: 79)

Przywołana formuła wychowania, jak twierdzi Krzysztof Maliszewski (2013: 87), „nie wzmacnia, ale uprzytomnia zwichnięcie”. Może właśnie dlatego w powolnej, uważnej interpretacji dostrzegam możliwość realizacji założeń takich idei pedagogicznych. Czytanie tekstów na warunkach wymykających się systemowi przypisującemu im treści od dawna przedyskutowane i ustalone, choć te wydają się ważne dla zrozumienia tradycji, jest oczywiście zajęciem ryzykownym, lecz podjęcie tego ryzyka może, choć nie musi, prowadzić do odkrycia rzeczy najwartościowszych, a w konsekwencji może pomóc wydobyć i skonstruować własny głos (tamże: 96).

\section{LEKTURA IMION}

Czytanie oznacza spotkanie z Innym (Koziołek 2006). Rzetelna lektura powinna skłaniać do uważnego przyjrzenia się imieniu, które Inny nosi. Prawdopodobnie znany i oswojony, a często dlatego nieciekawy tekst nabierze wtedy zupełnie nowego znaczenia. Poznać imię bohatera to odkryć go jeszcze raz. Włączenie nowych znaczeń w wyczytywanie sensów oznacza ich odnawianie,

3 Kategoria uważności coraz częściej pojawia się w dyskursie dydaktycznym (zob. Gielata 2016; Nussbaum 2016). 
które uczy przecież nieprzyzwyczajania się do kanonicznego rozumienia tekstów, skutecznie usypiającego czytelniczą aktywność. Warto tak zorganizować zajęcia, aby lekcje polskiego dawały możliwość spotkania z imieniem bohatera literackiego oraz z przywoływanym przez nie kontekstem, dla którego ramy literatury okazują się zdecydowanie za ciasne.

Józef Tischner, analizując znaczenie imienia, wskazał jego prymarny cel:

Przedstawiając drugiemu siebie, mówię mu, jakie jest moje imię, respective imię i nazwisko. Podstawową funkcją imienia jest wskazanie na człowieka jako na jednostkę. [...] Na ogół ustalił się pogląd, że poprzez imię zasadniczo niczego się nie poznaje z człowieka ani o człowieku. W każdym razie, poznanie imienia człowieka wcale nie oznacza poznania człowieka. (Tischner 2006: 222)

Choć trudno się nie zgodzić z tym twierdzeniem, to nie można zapominać o wciąż jednak żywym zainteresowaniu symboliką imion, które nawet jeśli nie prowadzi do poważnej egzegezy filologiczno-filozoficznej, to z pewnością jest podyktowane chęcią rozpoznania tego, który je nosi. Jak pisze Tischner: „Człowiek posiada imię, bo zna siebie w swoim imieniu i identyfikuje siebie poprzez swe imię. Dlatego może on drugiemu oznajmić swe imię i w ten sposób przedstawić się" (tamże: 223).

Imię jest więc znakiem rozpoznawczym, a jednocześnie przyzwoleniem na spotkanie, wszak wtedy mówimy sobie po imieniu, kiedy osiągniemy pozwalający na to stopień zażyłości. Wypowiadając czyjeś imię, czujemy się symbolicznie wtajemniczeni w świat Drugiego.

Jeśli jest nim Bóg, to obwarowanie artykulacji imienia rozmaitymi zakazami podkreśla jego „niewysłowiony” charakter. Niewypowiadalność Bożego imienia służy utrzymaniu granicy między człowiekiem a Absolutem, przeprowadzonej między tym, co wyrażalne a szem ha-meforasz, czyli „szczególnym Imieniem” Boga, które objawił Izraelowi. Tetragram JHWH4, odczytywany jako ,jestem, który jestem”, często na polski tłumaczony jest jako „Przedwieczny”, a nieraz jako „Pan”, co jest zgodne ze zwyczajem żydowskim. Jak przekonuje Stanisław Krajewski:

W trakcie liturgii lub studium tekstów religijnych jest ono [imię - M.W.D.] wymawiane jako hebrajskie słowo „Adonaj”, „mój pan”. Poza modlitwami jest natomiast oddawane jako „haszem”, czyli po hebrajsku „imię". Niezobowiązujące wspomnienie o Bogu czyni się więc, używając nazwy Imię. (Krajewski 1997: 35)

4 Warto zaznaczyć, że nie znamy sposobu wymawiania tetragramu. Podobno mędrcy raz na dwa lub siedem lat przekazywali swym uczniom oryginalną wymowę JHWH (por. Cohen 2002). 
Jeszcze inaczej nazywa Boga pierwszy hebrajski patriarcha. Abraham, wstawiając się za Sodomą, prosi Boga o wzgląd na sprawiedliwych:

Nie dopuść, byś miał uczynić coś podobnego, by uśmiercić sprawiedliwego wespół z bezbożnym, by sprawiedliwego spotkało to samo, co bezbożnego. Nie dopuść do tego! Czyż ten, który jest sędzią całej ziemi, nie ma stosować prawa? (Biblia 1979: Rdz. 18, 25).

Według tradycji judajskiej Boga sędziego najlepiej określa nazwa elohim, natomiast tetragram, przekładany - jak już wcześniej wspomniałam - jako „Pan”, wskazuje na jego miłosierdzie. Według Talmudu zestawienie obu imion: JHWH oraz elohim - tłumaczy istotę stworzenia świata i człowieka. Jeśli Bóg stworzyłby świat, kierując się jedynie miłosierdziem, to przyzwoliłby wtedy na plenienie się grzechu; jeśli stworzyłby go, bacząc tylko na sprawiedliwość, prawdopodobnie taki świat nie zdołałby przetrwać. Połączenie obu atrybutów gwarantuje równowagę ${ }^{5}$ Cohen 2002: 46).

O ile imię może być „odsłonięciem”, o tyle fałszywe imię jest próbą ukrycia się czy zamaskowania. Najlepiej ideę fałszywego imienia wyjaśnia Kartezjańska formuła "kroczenia w zamaskowaniu” (larvatus prodeo), będąca oceną kondycji ludzkiej. Człowiek jako „przezorny komediant” przybiera maskę, aby ukryć swój wstyd (Descartes 1989). Obraz zamaskowanego człowieka znakomicie wpisuje się $\mathrm{w}$ poetykę bohatera romantycznego ${ }^{6}$, będącego $\mathrm{w}$ stanie nieustannej metamorfozy, wchodzącego w coraz to nowe role czy w końcu zmieniającego swe imię. Ten nowy znak (byroniczny) rozpoznawczy albo unieważnia dotychczasowe życie (Gustaw-Konrad), albo ma je ukryć (Jacek Soplica - Ksiądz Robak) (Szewczyk 2016: 147-155).

Z pomocą „rozpoznaniu” człowieka dzięki egzegezie znaczenia jego imienia przychodzą rozmaite imionniki. Te najbardziej popularne odwołują się do onomastyki i spełniają przede wszystkim funkcje poznawcze. Imionniki poetyckie to odrębna kategoria tego typu tekstów. Zawierają literackie portrety imion, choć przecież tego typu zbiory, zwane również sztambuchem, libellus amicorum, liber memorialis, pierwotnie były rodzajem albumu służącego do wpisywania życzeń, wierszy, sentencji (Głowiński, Kostkiewiczowa, Okopień-Sławińska

5 Jak widać, znaczenie Bożych imion warto uczynić kontekstem interpretacyjnym obrazu Rembrandta Powrót syna marnotrawnego oraz jego literackiej ekfrazy - wiersza Wacława Oszajcy Syn marnotrawny - Rembrandt. Symbolikę rąk ojca na obrazie Rembrandta, przypominających jednocześnie dłoń kobiecą i dłoń męską, można wzbogacić o znaczenie imion elohim i JHWH.

6 Zagadnienie romantycznej realizacji idei zamaskowania zbadała Maria Janion (por. Janion 1980, 2006; Janion i Rosiek red. 1981). 
i Sławiński 2005: 558) czy po prostu do składania podpisów przez znane osobistości (Kotarski 1990).

Portrety imion Kazimiery Iłłakowiczówny, wydane w 1929 roku, stanowią przykład spójnej „narracji” wyznaczanej przez poetykę imionnika. Autorka w poetyckim wstępie tłumaczy zamysł tomiku stworzonego z liryków opisujących portrety imion. Przedstawia się w sytuacji opresyjnej, zmuszana jest bowiem do wypowiedzenia imienia ukochanego. Aby go nie zdradzić, naszkicowana sytuacja przypomina przesłuchanie, tortury, postanawia wykrzyczeć wszystkie imiona. Wśród nich ukrywa się również to najważniejsze. Taki koncept prowokuje do zbudowania układu wierszy prezentujących poszczególne imiona. Ich portrety są wypadkową tradycji, kontekstu współczesnego oraz odautorskiego komentarza:

\section{Barbara}

Obca wśród swoich, struchlała zawsze, gotowa z lęku do walki, bezbronna wobec dziecka, służącej rywalki

lubi pokoje, w których słońce na grubych pokładach kurzu leży, lubi ciszę, ciasnotę i mur gruby - tak by było coś na kształt wieży.

Szuka męczeństwa, brnie wszędzie, gdzie trud, znój, opór,

i patrzy tylko, gdzie by głowę położyć pod topór.

Lgnie do biednych, brudnych, chorych i nieporządnych, wielbi uczonych i śmieje się cicho z przesądnych.

Rzuca się jak lew w niebezpieczeństwo i lęka się pająka, myszy i kwiatu - Barbara męczennica, obca sobie i światu. (Iłłakowiczówna 1983: 20)

Hagiograficzna legenda uruchomiona przez imię zostaje poddana krytycznej obróbce. Znaczenie, które tradycja przypisuje imionom oraz cechy ich właścicieli zostały skonfrontowane ze współczesnością. Poetka, znana z zamiłowania do estetyki sentymentalnej, ale również z bezkompromisowych reinterpretacji kanonicznych obrazów (np. Opowieść matżonki świętego Aleksego), przekonuje, że nosiciel imienia bezwolnie przejmuje cechy nazwy, która go definiuje. W tym sensie imię, będące niemal Gombrowiczowską osaczającą formą, spełnia funkcję nowożytnego fatum. Teksty zamieszczone w tomiku prezentują dramatyczne napięcie między znaczeniem imion a jednostkowym losem ich nosicieli, ponieważ albo standardy etyczne wpisane w tradycję imienia okazują się zbyt wygórowane i nie przystają do pełnej kompromisów współczesności, albo „trywialność” konkretnej egzystencji nie wytrzymuje porównania z tradycją przywoływaną przez imię. 


\section{URUCHOMIĆ IMIĘ}

W przywołanych wyżej przykładach imię skutecznie utrudnia dostęp do swego nosiciela. Sprowadzone do brzmienia, które nazywa właściciela, stwarza dogodne warunki do spotkania, choć w rzeczywistości jest ono pozorne. Prawda tkwi raczej nie w dźwięku, a w znaczeniu imienia bądź w konfrontacji jego znaczenia z samym nazwanym. Praktyka czytania, której przyświeca przecież poszukiwanie sensu, z powodzeniem może uruchamiać imię, wydobywając jego znaczenia. Procedura lektury, choć atrakcyjna, z pewnością nie może stanowić uniwersalnej propozycji interpretowania tekstów. Sprawdziła się jednak w co najmniej dwóch przypadkach, dlatego w szkicu proponuję namysł nad dwoma tekstami na stałe wpisanymi do kanonu lektur: Akademiq pana Kleksa Jana Brzechwy oraz Antygonq Sofoklesa. Ten subiektywny wybór, zakładający uruchomienie znaczenia imion głównych bohaterów, wynika po pierwsze z „praktycznej", a nie jedynie z deklarowanej obecności wymienionych tekstów na lekcjach, a po drugie - z alternatywnej interpretacji w stosunku do tradycyjnych odczytań.

\section{PRZYPADEK PIERWSZY. AKADEMIA PANA KLEKSA, CZYLI EGZEGEZA IMION ${ }^{7}$}

Akademia, Adam i pozostali chłopcy „na A” - oto przestrzeń, w której panuje mentor, czyli pan Kleks. Trudno zgodzić się z tezą, że imiona bohaterów zaczynające się na literę A są dziełem przypadku. Oczywiście, sam Kleks tłumaczy ten antroponomastyczny elitaryzm niechęcią do zapamiętywania i zaśmiecania sobie pamięci innymi literami. Jednak atencja, jaką Kleks darzy literę A, a w języku hebrajskim alef, zachęca do głębszej refleksji. To samogłoska będąca w zapisie fonetycznym jedynie odmianą przydechu, ale znaczy więcej niż inne litery alfabetu (Zaderecki 1994). Otóż według kabalistów alef jest sumą trzech podstawowych form geometrycznych, które legły u podstaw powstania alfabetu hebrajskiego. Są nimi: punkt (od niego wszystko się zaczęło i odpowiada on literze jod), prosta (symbolizująca postawę pionową, odpowiada jej litera waw) i płaszczyzna (dwie linie układające się w literę L, odpowiada jej litera dalet).

7 Zaproponowaną interpretację można wykorzystać raczej w szkole ponadgimnazjalnej, a nie w szkole podstawowej. Z pewnością przywołanie lektury z dzieciństwa na lekcji z licealistami może wpłynąć na jej atrakcyjność, a „inna” interpretacja pomoże wzmocnić kontekst literacko-kulturowy wojennych tekstów wpisanych w kanon lektur omawianych w liceum (szerzej o praktykach czytania zob. Wójcik-Dudek 2016). 
Konstrukcja tych trzech liter tworzy kształt litery alef. Ona sama oznacza jedność Boga (Ouaknin 2006: 279-280).

Władysław Panas w tym hebrajskim znaku dostrzega podobieństwo do greckiej litery $x$ (chi), rozpoczynającej wyraz chiasmos, czyli „skrzyżowanie”. Dla badacza jest ono równoznaczne ze spotkaniem z Innym. Tak więc alef jest zapisem spotkania:

[Ta litera to - M.W.D.] symbol Boga i człowieka, który jedną ręką wskazuje niebo, drugą - ziemię, punkt początku. Można go [ów symbol - M.W.D.] określić, wybierając któryś z metafizycznych kierunków: od lewej (niebo) do prawej (ziemia) lub odwrotnie. Chiazm-alef odgrywa tu rolę podobną do „prześwitu” Heideggera. (Panas 1996: 77)

Trop dotyczący pisma oraz jego ukrytych sensów wydaje się szczególnie istotny dla opowieści o panu Kleksie. W kontekście lekcji kleksografii, przędzenia liter, zapisywania snów, porcelanowych tabliczek z tajemnicami czy w końcu wyprawy po atrament i samego imienia tytułowego bohatera wydaje się szczególnie ważny. Hebrajski jest przecież językiem świętym (leszon ha-kodesz), gdyż litery jego alfabetu mają tak niezwykłą siłę i energię, że stały się pierwotnymi narzędziami stworzenia. Należy pamiętać, że żydowscy kabaliści odrzucali stworzenie świata z niczego i dowodzili, że „Bóg stworzył świat widzialny, wzorując się na niewidzialnej Torze, a w związku z tym wszystkie stworzenia świata naśladują litery niewidzialnej, mistycznej Tory" (Markowski 2007: 185)

Konsekwencją tej doktryny jest wypracowanie specyficznego podejścia do interpretacji świata, w którym centralne miejsce zajmuje filozoficzny namysł nad poszczególnymi literami widzialnej Tory, a ich porządek znajduje odzwierciedlenie w otaczającym świecie.

Przejdźmy zatem do kolejnego szeregu liter, tym razem tworzącego imię. W tradycji hebrajskiej wyrzeczenie się imienia jest równoznaczne z rezygnacją z życia i języka, jak bowiem twierdzi Jacques Derrida (1998: 83), imię ma własne życie: „Mowa jest imieniem. To w imieniu drzemie siła języka, to ono jest pieczęcią otchłani, jaką on w sobie kryje”. Żydzi wierzą, że Bóg, posługując się imieniem, wezwie w dniu zmartwychwstania ${ }^{9}$ do powstania $\mathrm{z}$ grobu, a Talmud sugeruje, że zmiana imienia pozwala na odwrócenie Bożego wyroku.

8 Uwaga badacza może wymagać drobnego komentarza. Otóż według judaistycznej wykładni wszystkie stworzenia świata są literami mistycznej Tory.

9 Warto zaznaczyć, że w języku hebrajskim nie ma czasownika zmartwychwstać: „[...] na określenie »żyć« i »ożywić« używa się tego samego terminu. Z całą pewnością dlatego, że każde 
A zatem Adaś, Adam. W języku hebrajskim to określenie człowieka ${ }^{10}$ (Kuć 2001). Gematria przypisuje literom użytym w tym słowie wartość liczbową 45 , a tę z kolei zapisujemy jako ma, czyli „co?” (Ouaknin 2006: 70). Człowiek więc jest pytaniem o to, kim jest, a może bardziej - kim się staje i kim zamierza być. Ujęty w ramy takiej interpretacji, jest samą potencjalnością, czystą możliwością, którą zwykle przypisuje się tylko dziecku.

Adaś jako dwunastolatek trafia do Akademii, która ma go zmienić, poprawić i naprawić tak, aby z życiowego niezdary stał się człowiekiem sukcesu. Ma mu w tym pomóc mentor chłopców - pan Kleks. Ten jednak od razu wyjaśnia swoim uczniom zasady panujące w Akademii:

Pamiętajcie, chłopcy - rzekł do nas na samym początku pan Kleks - że nie będę was uczył ani tabliczki mnożenia, ani gramatyki, ani kaligrafii, ani tych wszystkich nauk, które są zazwyczaj wykładane w szkołach. Ja wam po prostu pootwieram głowy i naleję do nich oleju. (Brzechwa 1995: 37)

Co oznacza „pootwieranie głów” i „nalanie do nich oleju” w kontekście działań „edukacyjnych” pana Kleksa? Jego Akademia, inaczej niż wskazywałby na to wiek uczniów, nie jest chederem. Ten typ szkoły kojarzy się bowiem z przymusem, karami cielesnymi oraz surowym nauczycielem ${ }^{11}$. Wspaniały kilkupiętrowy gmach Akademii, stojący w parku sąsiadującym z krainami bajek, w niczym jednak nie przypomina chederu. Okazały trzypiętrowy budynek z salami przeznaczonymi do nauki i zabawy, tajemniczą przestrzenią należącą tylko do pana Kleksa i ogromnym ogrodem otoczonym murem ze szklaną bramą oraz trudnymi do policzenia furtkami prowadzącymi do poszczególnych baśni przypomina dobrze zorganizowaną instytucję, choć przecież Akademia jest wolna od opresyjnego systemu nauczania. Gmach przypominający bardziej pałac niż szkołę wspiera koncepcję baśniowości opowieści Brzechwy. Wychowankowie,

życie jest już zwycięstwem nad śmiercią, cudem, »być« nad »nie być«, zwycięstwem, które objawia istnienie ożywiającego, wiecznego Źródła" (Haddad 2012: 64).

10 Słowo to pochodzi od adama („ziemia”), czyli człowiek to „ziemianin”. Jednak „nie tyle mieszkaniec ziemi, co przede wszystkim wytwór ukształtowany z ziemi. [...] Zarazem adam to [...] akronim słów efer, dam, mara (»proch«, »krew«, »żółć«). Tak jak ziemia wydaje plony, tak człowiek musi być twórcą i wytwórcą przez pracę [...]. Ziemia jest przeznaczeniem człowieka istoty powstałej z ziemi" (Jędrzejewski 2012: 45).

11 Oczywiście mam na myśli stereotyp żydowskiej szkoły, którym chętnie operowali nie-Żydzi lub zwolennicy haskali. Mirosław Łapot (2014: 497) przywołuje określenie pojawiające się w oficjalnym „dyskursie” na temat oświaty. Otóż „Szkoła”, organ prasowy galicyjskiego nauczycielstwa ludowego, nazywa chedery „typem szkoły przedpotopowej”. 
przechodząc przez szklaną bramę, wkraczają do przestrzeni obietnicy, która nie dość, że nie każe „porzucić nadziei”, to jeszcze nakazuje uwierzyć w siebie.

Pan Kleks tworzy hybrydyczną instytucję, która spełnia po trochu kilka funkcji. Jest z pewnością szkołą, wielkim placem zabaw, ośrodkiem terapeutycznym ${ }^{12}$, w którym pomaga się chłopcom - podobnie jak zużytym sprzętom, które naprawia pan Kleks - uwierzyć w siebie. Droga do naprawy prowadzi przez rewolucję świadomości, swoistego rodzaju metanoię. Przemiana jest efektem dialogu między uczniem i nauczycielem. W tym sensie szkoła pana Kleksa przypomina trochę Akademię Platońską połączoną z chederem lub, uwzględniając wiek chłopców, z jesziwą. Dlatego też chederowy reb ${ }^{13}$ okazuje się jedynie nędzną karykaturą prawdziwego nauczyciela, przewodnika, za jakiego uchodzi pan Kleks. Jego wyjątkowość nie jest mierzona wyłącznie cudownymi umiejętnościami, które są oczywistymi atrybutami baśniowego bohatera, ale przede wszystkim podejściem do nauki i studiowania. Pobyt chłopców w Akademii, choć oddają ich tam rodzice, jest dobrowolny. Staje się ona swoistą arką, na której mogą przetrwać i czegoś się nauczyć ci, którzy dotąd nie najlepiej rokowali na przyszłość.

W języku hebrajskim czasownik studiować symbolizuje litera lamed - ל. Jako jedyna z dwudziestu dwóch liter alfabetu wychodzi ona poza linię pisma. Studiować oznacza więc 'wznosić się, przekraczać samego siebie, otwierać się na nieskończoność. Proces ten jest zazwyczaj dynamiczny, nie przebiega w ciszy i milczeniu, wpisuje się raczej w metaforyczny obraz pola walki niż w ascezę indywidualnych studiów. Towarzyszy mu gwar, ruch i towarzystwo drugiego studiującego, a nade wszystko - obecność mistrza. Wiedzę zdobywają w taki sposób nie tylko uczący się w bejt ha-midraszach, lecz także wychowankowie Akademii pana Kleksa.

Przekraczanie granic na podobieństwo litery lamed ma prowadzić do wykształcenia umysłu otwartego, do rozkwitu twórczej wyobraźni i odblokowania możliwości intelektualnych. Człowiek objęty takim wychowaniem „staje się”, a sam proces nauczania nigdy się nie kończy. Pan Kleks przekonuje, że interpretacja nie jest zastanym stanem rzeczy, lecz jedynie możliwością wprawiającą w ruch myślenie. Zadanie, jakie stawia sobie pan Kleks, sprowadza się zatem do wprawienia myśli w nieustanny ruch.

12 Gmach Akademii jest kompilacją różnych typów budynków, a co za tym idzie myślenia o przestrzeniach edukacji (zob. Nalaskowski 2002).

13 Istotne jest użycie terminu reb. Jan Garewicz (1999: 28) we wstępie do książki Martina Bubera wyjaśnia, że autor wprowadził „[r] ozróżnienie »rabbi« i »rabin« [...]. »Rabin« oznacza u niego prawowiernego duchownego żydowskiego, »rabbi« zaś to forma zwracania się powszechnie przyjęta u chasydów. Niekiedy zamiast »rabbi« tłumacz posługuje się formą »reb«; nigdy »rebbe« ze względu na polski zwyczaj językowy, w którym była to forma ośmieszająca”. 
Litera lamed, przekraczająca granice liniatury, wskazuje istotę studiowania. Jest ono nieustannym „wzlotem ku”, który nie pozwala się ująć w ostateczne definicje. Wynika to z twórczej niezgody na udzielenie odpowiedzi na pytanie wpisane w istotę człowieka: Adam - „co?”. Odpowiedź na nie byłaby końcem wędrówki, oznaczałaby stabilizację i zaprzeczałaby powołaniu człowieka, które realizuje się przez „bycie w drodze”.

Przybycie Alojzego staje się początkiem końca Akademii. Intencją chłopca i jego opiekuna Filipa nie jest z pewnością spotkanie oraz przypisywane mu samodoskonalenie, a tym bardziej kategorie związane z dialogiem i porozumieniem. Żydowska tradycja zezwala bowiem na to, aby uczeń powstał przeciw nauczycielowi, a nawet do tego zachęca. Alojzy jednak nie jest reprezentacją tego Innego, z którym można współistnieć. Jego żywiołem jest destrukcja, a nie tworzenie. Mechaniczna lalka, która ze względu na swą sztuczność nie jest predestynowana do dialogu, nigdy nie wpisze się w koncepcję braterstwa. Zresztą wyraźnie artykułuje swoje zamierzenia: „Będę wszystko niszczył, bo tak mi się podoba!” (Brzechwa 1995: 98). Towarzystwo chłopców go nudzi, a on sam chciałby szybko, w niemal „mechaniczny” sposób, posiąść całą wiedzę. Pan Kleks dostrzega nieludzkie tempo uczenia się swojego wychowanka i trudno mu je zaakceptować: „W gruncie rzeczy prześcignął nas wszystkich. Jest po prostu cudownym tworem. Nauczył się w Akademii wszystkiego i umie mówić nawet po chińsku. Zdaje mi się, że dosłownie zjadł mój słownik chiński, bo nigdzie go nie mogę znaleźć" (tamże: 98). „Pożeranie” książek przez Alojzego bynajmniej nie idzie w parze z umiłowaniem wiedzy: „Nie prosiłem pana Kleksa, aby uczył mnie myśleć. Mogłem bez tego się obejść" (tamże: 99).

Ten, który może obejść się bez myślenia, wybiera drogę na skróty. Pochłania bez zrozumienia i emocji książki, a chcąc pokonać mistrza, niszczy jego sekrety zapisane na porcelanowych tabliczkach. Jakie sensy kryje imię Alojzy? Ma pochodzenie germańskie i znaczy 'wszystko wiedzący' (al-wis, all-weisse) (Fros i Sowa red. 1997: 118). Noszący takie imię naznaczony jest pychą, która każe mu ignorować prawdę, że nieodłącznym towarzyszem nauki, czyli interpretacji, jest cierpliwość i gotowość na spotkanie. Wspólny mianownik stanowi niechęć do przemożnej potrzeby wyciągania wniosków, stawiania ostatecznych tez. Jednym słowem, skoro opowieść pana Kleksa o księżycowych ludziach została brutalnie przerwana w połowie zdania, to znaczy, że bunt maszyn kończy czas wolnej wyobraźni i dialogu.

Trudno w tej „wymianie” wartości nie dostrzec nawiązania do narodzin faszyzmu czy wybuchu II wojny światowej. Wskutek zniszczenia wspólnoty, jaką tworzył pan Kleks wraz ze swymi uczniami, zdekonstruowano odwieczny porządek, znajdujący odbicie nie tylko w relacjach między uczniem a nauczycielem, lecz także między poszczególnymi znakami - literami tworzącymi tekst. 
Potłuczenie porcelanowych tabliczek z zapisem tajemnic przypomina palenie książek w 1933 roku w Niemczech czy w ogóle niszczenie nieprawomyślnych dzieł przez systemy totalitarne.

Wraz ze zniszczeniem ksiąg i porcelanowych tabliczek przez Alojzego unicestwiono również język, gdyby bowiem:

[...] w boskim imieniu „Szaddaj” zabrakło punkcika, maleńkiej litery „jod”, pozostałoby samo „szod”, to znaczy spustoszenie. Ten punkcik sprawia, że straszliwa moc boża, która w każdej chwili mogłaby zupełnie spustoszyć i zniszczyć świat, wiedzie do jego zbawienia. Ten punkcik to prapunkt stworzenia. (Buber 1999: 36)

Alojzy nie tylko narusza porządek liter, lecz również porządek prawa - można powiedzieć, że nie działa zgodnie z jego literą.

Skoro zdołano unicestwić księgi, to możliwy jest też koniec Akademii. Bez niej zabraknie punktów orientacyjnych, które dotąd budowały poczucie bezpieczeństwa dzieci znajdujących się pod opieką pana Kleksa. Zniszczenie Akademii można więc rozpatrywać w kilku aspektach: jako koniec dzieciństwa, utratę Świątyni czy wybuch wojny. Wszystkie te interpretacje łączy jedno - Adaś i pozostali chłopcy zostaną banitami, wędrówka zaś, w którą wyruszą, okaże się prawdziwym sprawdzianem wartości, jakie przekazał im mistrz.

Akademia pogrąża się w ciemnościach, a wraz z nią cały świat ${ }^{14}$. Mrok jest konsekwencją utraty porządku świata, która ma związek z rozpadem porządku liter. Według biblijnej legendy Bóg stworzył światło ze swego drugiego imienia:

Potem znowu otworzył pismo, wziął drugie imię i zrobił z niego trzy krople światła. Z najjaśniejszej uczynił światło oświetlające ogród Edenu; z drugiej kropli stworzył światło, które zaświeci w dniach Mesjasza [...]. Z trzeciej kropli zrobił Pan światło dla tego świata. (bin Gorion 1996: 19)

Bunt Alojzego nie tylko stanowi akt sprzeniewierzenia się odwiecznym regułom, lecz także jest wyrazem chęci zaciemniania fundamentalnych sensów,

14 Zastanawiający jest fakt zmniejszania się pana Kleksa. Wraz z pojawieniem się Alojzego w Akademii profesor powoli opada z sił, staje się coraz mniejszy. Wydaje się, że podlega cimcum. Pojęcie to oznacza wycofanie się Boga w głąb samego siebie: „Istniejąca w łonie chasydyzmu sekta Chabad rozumiała je czasem w ten sposób, że Bóg po prostu pozwolił człowiekowi postrzegać świat, który z boskiego punktu widzenia w ogóle nie istnieje” (Unterman 1989: 131). Oczywiście fabuła opowieści Brzechwy nie pozwala na przypisywanie Ambrożemu Kleksowi boskich atrybutów niemniej „zerowanie” siebie, aby dać wolność innym, jest niesłychanie interesującym tropem w kontekście interpretowania tej postaci jako nauczyciela i mentora. 
których metonimią są litery budujące zwarte szeregi słów. Adaś zatem musi zdobyć światło - atrament, dzięki któremu będzie możliwe zapisywania świata, ponieważ to litery stanowią gwarancję jego istnienia. Ostatecznie więc ta wyprawa będzie miała charakter restytutywny, co oznacza, że jej celem jest przywrócenie światu kształtu sprzed katastrofy. Pan Kleks i Adaś mają do wykonania trudne zadanie polegające na przeprowadzeniu świata z ciemności, która oznacza stagnację, niewiedzę i niemożność zapisu, w blask utożsamiany z wolnością, wiedzą i zapisem opowieści.

Bohaterowie osiągną cel w ostatnim tomie trylogii - Tryumfie pana Kleksa. Zanim to jednak nastąpi, pan Kleks pozostaje figurą wprowadzającą ontologiczny, a co za tym idzie filologiczny niepokój. Wciąż „się staje” - pod koniec pierwszego tomu jest guzikiem, w finale drugiego zamienia się w butlę atramentu, aby w trzecim przedzierzgnąć się w ptaka. Tym samym pan Kleks wymyka się nie tylko formom, ale i nazwom. Poza jedną.

CZEŚNIK

$[\ldots]$

Cóż to jest?

DYNDALSKI

podnoszac się

Żyd, jaśnie panie.

Lecz w literę go przerobię. (Fredro 1987: 146)

Żydem bowiem nazywano plamę atramentu. Tym sposobem żydostwo zostało włączone w ontologię Pana Kleksa. Może więc warto dostrzec w nim Żyda, którego żywiołem pozostaje język należący do porządku Księgi?

\section{PRZYPADEK DRUGI - ANTYGONA. DLACZEGO BOHATERKA SOFOKLESA JEST ANTY?}

W Prologu dramatu Antygona zadaje swej siostrze fundamentalne pytanie dotyczące tego, czy Ismena słyszała zakaz Kreona. Kiedy ta zaprzecza, Antygona zapowiada, że się mu przeciwstawi. Jednocześnie nie zgadza się, aby siostra zachowała jej czyn w tajemnicy. Wręcz przeciwnie, tylko głośne mówienie o pogwałceniu prawa stanowionego przez władcę może nadać jej gestowi odpowiednią rangę. Jak pisze Judith Butler (2010), „mówienie” o nim włącza kobietę w ogólny dyskurs należący do tej pory wyłącznie do mężczyzn. 
To feminizujące czytanie Antygony przełamuje niejako monopol na interpretację dramatu, długo pozostającego przecież pod wpływem analizy Georga W.F. Hegla, który w tragedii Sofoklesa dostrzegł przede wszystkim konflikt dwóch równoprawnych sfer wartości (Lesky 2006: 53-62).

Inspirowana alternatywną interpretacją szkolna (uważna) lektura Antygony może prowadzić do zaskakujących odkryć, choćby takiego, że dramat jest częścią trylogii, do której w kolejności należą Król Edyp i Edyp w Kolonie, a Antygona w tym fabularnym szeregu zajmuje ostatnie miejsce. Przeczytanie trzech tragedii antycznych jest dla ucznia zadaniem karkołomnym, tym niemniej świadomość istnienia trylogii o rodzie Labdakidów ma ogromny wpływ na sposób dekonstruowania kanonicznego czytania Antygony.

W drugiej części trylogii, zatytułowanej Edyp w Kolonie, bohaterowie otrzymują schronienie na dworze Tezeusza, władcy Aten. Antygona jest przewodniczką i nieodłączną towarzyszką ślepego ojca skazanego na wygnanie. Wkrótce Edyp dowiaduje się, że synowie zabronili mu powrócić do Teb oraz że zwrócili się przeciwko sobie w bratobójczej walce o tron. Niedługo potem Polinejkes odwiedza ojca i wzywa go do powrotu. Edyp odmawia. Wydaje się, że Antygona widzi i rozumie więcej od pozostałych. W losie brata, który będzie uchodzić za zdrajcę, dostrzega nie tylko swoje przeznaczenie, lecz także całej swej rodziny. Dlatego błaga Edypa, aby okazał litość Polinejkesowi. Butler przekonuje, że Antygonę spotka dokładnie ten sam los, który wcześniej zapowiedziała bratu. Tak jak on idzie przecież „na śmierć z otwartymi oczami”. Przy tak intensywnej ekspozycji roli fatum w labdakijskim micie kwestia tragicznego wyboru lub konfliktu tragicznego traci swoje logiczne umocowanie. Taką intuicją wykazała się również Maria Janion, jedna z najbardziej przenikliwych współczesnych czytelniczek kanonicznych dzieł Sofoklesa i Mickiewicza:

Czasem sądzono, że to „nieposłuszeństwo” Antygony i porównywano „zdrady” obu bohaterek tragicznych. W wypadku Grażyny trzeba jednak mówić o szczególnej postaci „zdrady” - tak, jak ją sama Grażyna nazywa i mając to, co ona. W wypadku Antygony - nie: ona przeciw dekretom Kreona reprezentuje tzw. prawo naturalne, a w przekonaniu o absolutnej słuszności racji własnego sumienia widać znamię hybris. [...] Grażyna przekracza to, co ustanowione, ale w utajnieniu i z poczuciem winy (niezawinionej). Tego poczucia zupełnie nie ma w Antygonie, dlatego może również niektórzy nie widzą w niej tragizmu. (Janion 2006: 88-89)

Ale to nie wszystko. Warto zająć się etymologią imienia głównej bohaterki - oznacza ono 'na miejscu matki': 
Przyimek anti oznacza zarówno 'w przeciwieństwie do', jak 'zamiast czegoś'; gone należy do derywatów słowa genom ('krewny, z tej samej linii, potomek') i znaczy jednocześnie 'potomek, pokolenie, łono, nasienie i narodziny'. Na podstawie tej etymologicznej polifonii (walki o znaczenie u samych podstaw imienia) możemy stwierdzić, że Antygona opowiada się po stronie rodziny, a przeciwko miastu (kompensując $\mathrm{w}$ ten sposób klęskę w czasie reform przeprowadzonych przez demos), jak też sprzeciwia się rodzinie, co znajduje wyraz w jej przywiązaniu do brata i pragnieniu zrywającym więzi, philia poza rodziną. (Gourgouris 2003, cyt. za: Butler 2010: 36)

Jej imię jest jednocześnie złożeniem, które można sprowadzić do terminu antygeneracja (gone to 'generacja, pokolenie'). Antygona znalazła się przecież w zasięgu fatum ciążącego na całym rodzie, a więc nie będzie kochać mężczyzny, nie będzie rodzić dzieci. Skoro Edyp zaczyna się do niej zwracać jak do mężczyzny (aner), to wymusza na niej stosowne zachowanie. W takim kontekście słowa Antygony skierowane do Ismeny nabierają nowego znaczenia:

Słychać, że Kreon czci godny dla ciebie,

Co mówię, dla mnie też wydał ten ukaz

I że tu przyjdzie, by tym go ogłosić,

Co go nie znają, nie na wiatr zaiste

Rzecz tę stanowiąc, lecz grożąc zarazem

Kamienowaniem ukazu przestępcom.

Tak się ma sprawa; teraz wraz ukażesz.

Czyś godną rodu, czy wyrodną córą. (Sofokles 1984: 7)

Inny fragment:

A jednak skąd bym piękniejszą ja sławę

Uszczknęła, jako z brata pogrzebania? (tamże: 26)

I jeszcze:

[...], a ja brata

Pogrzebię sama, potem zginę z chlubą.

Niechaj się zbratam z mym kochanym w śmierci

Po świętej zbrodni. (tamże: 9) 
Motywacja działań Antygony nie wynika jedynie z posłuszeństwa boskim prawom, ale jest podyktowana również „męską” chęcią sprawdzenia się, walką z własnymi słabościami. Skoro ojciec zwraca się do niej jak do mężczyzny, to ona sama musi wejść w stosowną rolę. Antygona, łamiąc zakaz, symbolicznie wchodzi na agorę. O jej czynie się mówi.

Kobieta dzięki symbolicznemu gestowi, będącemu jedynie substytutem rytuału grzebania (na zwłoki brata sypie garść ziemi), dokonuje symbolicznego pochówku także swego ojca. Postępek Edypa nie pozwala przecież, aby jego zwłoki spoczęły w tebańskiej ziemi. Tezeusz potajemnie grzebie jego ciało. Jak twierdzi Butler (2010: 233), Antygona powtarza ten sam rytuał pochówku, którym objęte są już dwie osoby - syn i ojciec ${ }^{15}$.

Ten symboliczny gest, oprócz wspomnianego wcześniej, posiada jeszcze jedno znaczenie. Hans Belting (2012: 78-79) zauważa, że „[z]marły wywołuje słynne pytanie o Gdzie. Wraz z utratą ciała traci on także swoje miejsce. [...] Poszukiwanie zmarłego jest w większości kultur historycznych poszukiwaniem miejsca”. Grób stanowi zatem gwarancję miejsca i stałości. Ale nie tylko. Według badacza grób nie jest jedynie miejscem spoczynku, lecz także działania, w którym na nowo został wynaleziony czas śmierci: „Katastrofa śmierci zostaje zamieniona na kontrolę śmierci o tyle, o ile wspólnota społeczna - przez uroczyste działanie - odtwarza sobie swój porządek" (tamże: 80). Spalenie, ofiarowanie wina i stypa, którym towarzyszyły ekstatyczny lament i płacz, dopomagały zmarłemu w spełnieniu prawa do rytualnej śmierci, dzięki której na powrót otrzymywał tożsamość służącą mu jako przepustka do Hadesu. Aktywność członków wspólnoty jest więc konieczna, aby wydarzenie biologiczne - śmierć - mogło zostać przekształcone w wydarzenie społeczne, czyli w pogrzeb.

Antygona, przysypując zwłoki garstką ziemi, pragnie wpisać zmarłego w społecznie sankcjonowany porządek. Prywatny gest przekształca w skandal mówienia. Plan zapowiedziany w prośbie skierowanej w Prologu do Ismeny, aby ta głośno mówiła o złamaniu przez Antygonę prawa, realizuje się w konkretnym czynie. Tym samym często cytowane na lekcji polskiego słowa Kreona: „Teraz przed drugim nie sroma się gwałtem, / Z czynu urąga. / Lecz nie ja mężem, lecz ona by była. / Gdyby postępek ten jej uszedł płazem" (Sofokles 1984: 26), nie oznaczają jedynie sprzeciwu mężczyzny, władcy, przyszłego teścia wobec wybryku Antygony, lecz także wyrażają przeczucie Kreona, że - jak twierdzi Butler

15 Zagadką jest powtórny powrót Antygony do ciała Polinejkesa. Według Albina Lesky’ego (2006: 233) „podwójny pogrzeb jest konieczny ze względu na akcję sztuki: udana ceremonia i ucieczka umożliwiają pierwszą scenę ze strażnikiem, która znów wywołuje ekspozycję Kreona i tak zwiększa napięcie, że konfrontacja obojga przeciwników - po schwytaniu Antygony przy drugiej próbie - może przebiegać niezwykle emocjonalnie”. 
- przyszła synowa dzięki buntowi i wejściu w przestrzeń męskiego dyskursu pozbawi go tego, co najbardziej męskie - prawa do stanowienia. Jej postępek wytrąca z obowiązujących dotąd norm, które zapewniały mężczyźnie stabilne miejsce we wspólnocie i gwarantowały wyłączność sprawowania władzy (Butler 2010: 17). O ile stabilność, suwerenność, gwarancja oraz miejsce charakteryzują Kreona, a tym samym pozycję mężczyzny, o tyle pojęcia te są antonimami w odniesieniu do samej Antygony. Mówiąc „nie”, kobieta wyklucza się ze wspólnoty. Anty, symbol tego wykluczenia, jest wpisany w imię Antygony.

Jak widać, analiza imienia tytułowej bohaterki może prowadzić do zaskakujących interpretacji. Takie praktyki nie stanowią zagrożenia dla „kanonicznego” czytania antycznego dramatu. Mogą stanowić jednak cenne uzupełnienie lekcji, na której w „tradycyjny” sposób charakteryzuje się bohaterkę lub przeprowadza sąd literacki. Namysł nad znaczeniem imienia, wymagający filologicznej refleksji, uruchamia pracę sensów, które czynią z lektury doświadczenie niejednoznaczności, o które upomina się Maliszewski (2013). To właśnie ono, jak żadne inne, otwiera przed uczniem nowe horyzonty.

\section{ETYKA SAMARYTANINA}

Przemysław Czapliński (2005: 63) twierdzi, że obecnie style odbioru literatury „są kształtowane nie przez recenzentów, lecz przez szkołę, dom, Kościół i codzienną komunikację publiczną. Czytamy książki nie tak, jak nas nauczono czytać, lecz tak, jak nas wychowano do komunikacji”. Pozostaje wierzyć, że pytanie o imię Innego, troska o detal i uważność towarzysząca lekturze przełożą się na mądre i świadome spotkania poza tekstem. Taki cel można osiągnąć, jeśli z miarodajnych dzieł nie uczynimy nieruchomej miary, tylko podtrzymamy w onieśmielających Wielkich Księgach (Maliszewski 2013: 86) ciągły ruch sensów. Prowadzi on do ćwiczenia chyba najistotniejszej dyspozycji człowieka - umiejętności porzucania utartych dróg, a tym samym gotowości do bycia na rozdrożu. Sławek (2019: 19), opisując tę zdolność, sięga po jedną z takich Wielkich Ksiąg: „Dopiero Samarytanin okazał się zdolny do tego, by złamać swój plan podróży, odrzucić niewolący magnetyzm punktu przeznaczenia wyprawy, opóźnić jej przebieg, a zapewne w konsekwencji narazić się na stratę". Wybór Samarytanina był rezultatem empatycznego spojrzenia, które „wstrząsa całą konstrukcją mojej egzystencji” (tamże: 20). I choć spojrzenie w oczy Innego, ciekawość, kim jest, zawarta w pytaniu o jego imię, skutecznie przeszkadzają w wędrówce, znosząc ją na nowe trajektorie, to przyzwolenie na tego rodzaju błądzenie wydaje się nie tylko prawem wpisanym w lekturę i życie, ale przede wszystkim etyczną powinnością wobec tekstu i drugiego człowieka. 


\section{BIBLIOGRAFIA}

Belting, H. (2012). Obraz i śmierć. W: K. Kurz, P. Kwiatkowska, Ł. Zaremba (red.), Antropologia kultury wizualnej. Zagadnienia i wybór tekstów (s. 73-83). Warszawa: Wydawnictwa Uniwersytetu Warszawskiego.

Biblia. (1979). Nowy przekład z języków hebrajskiego i greckiego opracowany przez Komisję Przekładu Pisma Świętego. Warszawa: Brytyjskie i Zagraniczne Towarzystwo Biblijne.

Brzechwa, J. (1995). Akademia pana Kleksa Warszawa: Czytelnik.

Buber, M. (1999). Gog i Magog. Kronika chasydzka. Warszawa: PWN.

Butler, J. (2010). Żądanie Antygony. Rodzina między życiem a śmiercia. Kraków: Księgarnia Akademicka.

Cohen, A. (2002). Talmud. Syntetyczny wyktad na temat Talmudu i nauk rabinów dotyczacych religii, etyki i prawodawstwa. Warszawa: Wydawnictwo Cyklady.

Czaplicka-Jedlikowska, M. (2007). Edukacyjne aspekty nazw wtasnych w literaturze dla dzieci. Bydgoszcz: Wydawnictwo Uniwersytetu Kazimierza Wielkiego.

Czapliński, P. (2005). Powrót centrali? Literatura w nowej rzeczywistości. W: G. Matuszek (red.), Literatura wobec nowej rzeczywistości (s. 61-72). Kraków: Księgarnia Akademicka.

Dawidziak-Kładoczna, M. (2015). Mechanizmy kreacji onimów w literaturze dla dzieci (na przykładzie wybranych utworów). Onomastica, t. 59, 341-354, DOI: https:// doi.org/10.17651/ONOMAST.59.21.

Derrida, J. (1998). Jednojęzyczność innego, czyli proteza oryginalna. Literatura na Świecie, nr 11-12, 328-329.

Descartes (1989). Cogitationes privatae. W: F. Alquié, Kartezjusz. Warszawa: Instytut Wydawniczy „Pax”.

Fredro, A. (1987). Zemsta. Wrocław: Zakład Narodowy im. Ossolińskich.

Fros, H., Sowa, F. (red.). (1997). Księga imion i świętych (T. 1). Kraków: Wydawnictwo WAM.

Garewicz, J. (1999). Sprawiedliwi, pobożni i świat. Gog i Magog- impresje z lektury. W: M. Buber, Gog i Magog. Kronika chasydzka (s. 4-22). Warszawa: PWN.

Gielata, I. (2016). Lekcje uwagi - między obrazem a filmem. W: W. Hajduk-Gawron, M. Wójcik-Dudek (red.), Film $i$ serial $w$ dydaktyce $i$ glottodydaktyce polonistycznej (s. 6-7). Katowice: Uniwersytet Śląski w Katowicach. Pobrane z: http://serwer1573845.home.pl/pub/US_SEM4/index.html\#p=3 [dostęp: 10.11.2019].

Głowiński, M., Kostkiewiczowa, T., Okopień-Sławińska, A., Sławiński, J. (2005). Słownik terminów literackich. Wrocław: Zakład Narodowy im. Ossolińskich.

Gorion, M.J. bin (1996). Żydowskie legendy biblijne (Cz. 1). Gdynia: „Uraeus”.

Gourgouris, S. (2003). Literature as Theory (for an Antimythical Era). Stanford: Stanford University Press.

Grodziński, E. (1973). Zarys ogólnej teorii imion własnych. Warszawa: PWN.

Grzeszczuk, S. (1963). Przedmiot i zadania nazewnictwa literackiego. W: Z polskich studiów slawistycznych. Seria 2. Nauka o literaturze (s. 383-405). Warszawa: PWN. Haddad, Ph. (2012). Mądrości rabinów. Warszawa: Wydawnictwo Cyklady. 
Iłłakowiczówna, K. (1983). Portrety imion. Poznań: Wydawnictwo Poznańskie. Janion, M. (1980). Odnawianie znaczeń. Warszawa: Wydawnictwo Literackie.

Janion, M. (2006). Kobieta-Rycerz. W: tejże, Kobiety i duch inności (s. 78-101). Warszawa: Wydawnictwo Sic!

Janion, M., Rosiek, S. (red.). (1981). Galernicy wrażliwości. Gdańsk: Wydawnictwo Morskie.

Jędrzejewski, P. (2012). Judaizm bez tajemnic. Kraków: Pardes.

Kęsikowa, U. (1988). Funkcja dydaktyczna nazewnictwa w powieściach dla młodzieży. W: E. Homa (red.), Onomastyka w dydaktyce szkolnej i spotecznej (s. 81-86). Szczecin: Wydawnictwo Naukowe Uniwersytetu Szczecińskiego.

Kotarski, E. (1990). O imionnikach XVI i XVII wieku. W: H. Dziechcińska (red.), Staropolska kultura rękopisu (s. 93-111). Warszawa: IBL PAN.

Koziołek, K. (2006). Czytanie z innym. Etyka, lektura, dydaktyka. Katowice: Wydawnictwo Uniwersytetu Śląskiego.

Krajewski, S. (1997). Żydzi, judaizm, Polska. Warszawa: „Vocatio”.

Kuć, W. (2001). Dziecko w judaizmie. W: M.S. Ziółkowski (red.), Antropologia religii. Wybór tekstów (T. 2; s. 55-71). Warszawa: Wydawnictwo Uniwersytetu Warszawskiego.

Lech-Kirstein, D. (2016). Onomastyka literacka a onomastyka stylistyczna. Stylistyka, t. 25, 457-466.

Lesky, A. (2006). Tragedia grecka. Kraków: Homini.

Łapot, M. (2014). Chedery lwowskie w okresie autonomii galicyjskiej (1867-1914). Kwartalnik Historii Żydów, nr 3, 496-512.

Łuc, I. (2007). Nazwy wtasne w literaturze dziecięco-mtodzieżowej. Katowice: Wydawnictwo Uniwersytetu Śląskiego.

Maliszewski, K. (2013). Ciemne iskry. Problem aktualizacji pedagogiki kultury. Toruń: Wydawnictwo Adam Marszałek.

Markowski, M.P. (2007). Polska literatura nowoczesna: Leśmian, Schulz, Witkacy. Kraków: Universitas.

Nalaskowski, A. (2002). Przestrzenie i miejsca szkoty. Kraków: Oficyna Wydawnicza Impuls.

Nussbaum, M. (2016). Nie dla zysku. Dlaczego demokracja potrzebuje humanistów. Warszawa: Fundacja Kultura Liberalna.

Ouaknin, M.A. (2006). Tajemnice kabaty. Warszawa: Wydawnictwo Cyklady.

Panas, W. (1996). Pismo i rana. Szkice o problematyce żydowskiej w literaturze polskiej. Lublin: Dabar.

Rajewska, E. (2013). Garść uwag o „The Wind in the Willows” Kennetha Grahame'a w adaptacji Alana Bennetta (1991) i przekładzie Doroty Maliny (2011). W: M. Osiecka (red.), Wkład w przektad (s. 267-271). Kraków: Korporacja Ha!art.

Rybicka, K. (2013). Mr. Leathercow czy Pan Żeberko? Tłumaczenie imion i nazwisk w literaturze dziecięcej. W: M. Osiecka (red.), Wktad w przekład (s. 43-53). Kraków: Korporacja Ha!art.

Rymut, K. (1993). Onomastyka literacka a inne dziedziny badań nazewniczych. W: M. Biolik (red.), Onomastyka literacka (s. 15-19). Olsztyn: Wydawnictwa Wyższej Szkoły Pedagogicznej. 
Sławek, T. (2002). Antygona w świecie korporacji. Rozważania o uniwersytecie i czasach obecnych. Katowice: Wydawnictwo Uniwersytetu Śląskiego.

Sławek, T. (2019). Alicja, czyli o co chodzi w uczeniu. W: W. Bobiński, J. Sujecka-Zając (red.), Ksztatcenie nauczycieli - wyzwanie i zaangażowanie (s. 11-29). Kraków: TAiWPN Universitas.

Sofokles (1984). Antygona. Wrocław: Zakład Narodowy im. Ossolińskich.

Szestow, L. (2011). Apoteoza niezakorzenienia. Próba myślenia adogmatycznego. Warszawa: Wydawnictwo KR.

Szewczyk, Ł.M. (1990). Funkcje artystyczne nazewnictwa biblijnego w „Dziadach cz. III" Adama Mickiewicza. Onomastica, t. 35, 91-102.

Szewczyk, Ł.M. (2016). Funkcja wartościująca nazewnictwa literackiego (na materiale wybranych dzieł Adama Mickiewicza). Stylistyka, 147-155.

Szymańska, I. (2014). Przekłady polemiczne w literaturze dziecięcej. Rocznik Przekładoznawczy. Studia nad Teorią, Praktyką i Dydaktyką Przekładu, nr 9, 193208, DOI: http://dx.doi.org/10.12775/RP.2014.014.

Tischner, J. (2006). Filozofia dramatu. Kraków: Znak.

Unterman, A. (1989). Żydzi. Wiara i życie. Łódź: Książka i Wiedza.

Wilkoń, A. (1970). Nazewnictwo w utworach Stefana Żeromskiego. Wrocław: Zakład Narodowy im. Ossolińskich; Wydawnictwo PAN.

Wójcik-Dudek, M. (2016). W(y)czytać Zagładę. Praktyki postpamięci w polskiej literaturze XXI wieku dla dzieci i mtodzieży. Katowice: Wydawnictwo Uniwersytetu Śląskiego.

Zaderecki, T. (1994). Tajemnice alfabetu hebrajskiego. Warszawa: Agade Bis Magdalena Kapełuś. 